Original article

\title{
Effects of the level and source of dietary protein on intake and milk yield in dairy cows
}

\author{
Dhiaeddine M’HAMED*, Philippe FAVERDIN, Raymond Verité \\ INRA/ENSAR Unité Mixte de Recherches Production du Lait, 35590 Saint-Gilles, France
}

(Received 27 July 2000; accepted 27 March 2001)

\begin{abstract}
The objectives of this trial were to determine the effect of dietary protein content and the effect of the source of protein supplements on dry matter intake (DMI) and milk yield in dairy cows fed ad libitum. In addition, the interaction of protein supplement with the level of milk yield was studied to test the hypothesis that the DMI response to protein supplement depends on the nutrient requirements of the cows. Two groups of six lactating cows differing in milk yield $\left(45 \mathrm{~kg} \cdot \mathrm{d}^{-1}\right.$ and $38 \mathrm{~kg} \cdot \mathrm{d}^{-1}$ pre-treatment) were assigned to a double $3 \times 3$ Latin square design over periods of 3 weeks. The 3 treatments consisted of 3 complete diets (60\% maize silage and $40 \%$ concentrate) with different protein sources and levels: low-protein supplement (LP) (5\% soybean meal $+1.2 \%$ of urea in the diet), high-protein supplement containing soybean meal (HP-SB) (19\% soybean meal) and high-protein supplement containing formaldehyde-treated soybean meal (HP-FTSB) (12\% formaldehyde-treated soybean meal $+1.2 \%$ of urea in the diet). HP treatments significantly increased $(P<0.05)$ DMI $\left(+1.2 \mathrm{~kg} \cdot \mathrm{d}^{-1}\right)$, milk yield $\left(+1.8 \mathrm{~kg} \cdot \mathrm{d}^{-1}\right), 4 \%$ FCM $\left(+2.5 \mathrm{~kg} \cdot \mathrm{d}^{-1}\right)$ and fat content $\left(+1.9 \mathrm{~g} \cdot \mathrm{kg}^{-1}\right) \mathrm{com}-$ pared to the LP treatment. These improvements were not related to the source of protein used or the level of milk yield. Compared to LP treatment, the HP-SB treatment increased milk protein content $\left(+1.4 \mathrm{~g} \cdot \mathrm{kg}^{-1}\right)(P<0.05)$, whereas the HP-FTSB treatment had no significant effect. Intake and milk yield were increased by higher protein content in the diets independently of the source of protein used or the level of milk yield.
\end{abstract}

dairy cow / intake / protein / milk yield

Résumé - Effet du traitement de tannage des protéines au formol sur l'ingestion et la production des vaches laitières. Cet essai a pour objectif d'étudier l'effet de la teneur et de la nature des protéines de la ration sur les quantités ingérées et la production laitière chez les vaches laitières alimentées à volonté. De plus, le dispositif expérimental utilisé a permis d'étudier l'interaction entre le supplément protéique et le niveau de production afin de savoir si la réponse d'ingestion à un supplément de protéines était fonction des besoins nutritionnels des vaches. Deux groupes de six vaches laitières constitués selon le niveau de production $\left(45 \mathrm{~kg} \cdot \mathrm{j}^{-1}\right.$ et $\left.38 \mathrm{~kg} \cdot \mathrm{j}^{-1}\right)$ ont été répartis dans un schéma en double carré latin $3 \times 3$ avec des périodes de 3 semaines. Les traitements consistaient en : (1) un régime témoin négatif (LP) (5\% tourteaux de soja $+1,2 \%$ d'urée dans la ration), (2) un régime tourteaux de soja (HP-SB) (19\% de tourteaux de soja) et (3) un régime tourteaux de soja tanné (HP-FTSB) (12\% de

* Correspondence and reprints

Tel: 33 (0)2 234850 82; fax: 33 (0)2 234851 01; e-mail: mhamed@ st-gilles.rennes.inra.fr 
tourteaux tannés $+1,2 \%$ urée dans la ration). L'accroissement de la teneur de la ration en protéines alimentaires peu dégradables dans le rumen par rapport au régime témoin entraîne des augmentations significatives $(P<0,05)$ des quantités ingérées $\left(+1,2 \mathrm{~kg} \cdot \mathrm{j}^{-1}\right)$, de la production laitière $\left(+1,8 \mathrm{~kg} \cdot \mathrm{j}^{-1}\right)$, des quantités de lait standard $\left(+2,5 \mathrm{~kg} \cdot \mathrm{j}^{-1}\right)$ et du taux butyreux $\left(+1,9 \mathrm{~g} \cdot \mathrm{kg}^{-1}\right)$. Comparée au régime témoin (LP), l'utilisation des tourteaux de soja normaux améliore le taux protéique du lait $\left(+1,4 \mathrm{~g} \cdot \mathrm{kg}^{-1}\right)$ contrairement aux tourteaux tannés. Les quantités ingérées et la production laitière sont augmentées chez la vache laitière par la supplémentation de protéines dans le régime indépendamment de la nature du supplément protéique et du niveau de production.

vaches laitières / ingestion / protéines alimentaires / production laitière

\section{INTRODUCTION}

In ruminants, increasing the protein content of the diet enhances DMI, milk yield and body weight gain $[3,20]$, but the responses vary greatly according to the type and level of protein supplements. The supplementation of diets with non-degradable protein improves milk yield in dairy cows $[1$, $7,13]$, but DMI responses vary among the different trials $[11,14,26]$. On the one hand, heat-treated or formaldehyde-treated protein supplements are the usual source of PDIA (dietary protein truly digested in the small intestine) [24] used in dairy production, but heat-treatment of proteins may decrease their digestibility in the small intestine [6]. On the other hand, formaldehyde can affect microorganism activities and consequently alter digestion [16].

Whether rations are offered to dairy cows with formaldehyde-treated or non-treated protein supplements, improvements in milk yield are the same and a large amount of protein supplement is economised [23]. Nevertheless, few trials have been conducted with cows fed ad libitum in order to compare different protein sources allowing the same contribution of PDIE (protein truly digested in the small intestine allowed by energy) and PDIN (protein truly digested in the small intestine allowed by nitrogen) [24] in the rations, and to verify the consequences of formaldehyde treatment on intake. Some authors have suggested that the response of dairy cows to protein supply could be influenced by their potential yield, but these authors were interested only in parity and did not compare the responses of multiparous cows according to their milk yield [12].

The objectives of this trial were (1) to verify that enhancement of protein digestible in the intestine (PDI) improves DMI, (2) to see if the formaldehyde treatment of soybean meal affects DMI at similar levels of PDI supply, and (3) to verify whether the DMI response to protein supplements differs with the milk yield in dairy cows.

\section{MATERIALS AND METHODS}

\subsection{Experimental procedure}

Three complete diets with different protein supplements were compared in two groups of high and medium milk-yielding cows using a split-plot experimental design. Twelve multiparous cows at the beginning of lactation (58 days postpartum) were divided into two groups according to milk yield $\left(44.8 \pm 5 \mathrm{~kg} \cdot \mathrm{d}^{-1}\right.$ and $37.7 \pm 2 \mathrm{~kg} \cdot \mathrm{d}^{-1}$ for groups 1 and 2 , respectively) and body weight $(643 \pm 60 \mathrm{~kg}$ and $614 \pm 65 \mathrm{~kg}$ for groups 1 and 2, respectively) during the preexperimental week. Cows in each group were assigned successively to 3 experimental diets according to a double $3 \times 3$ Latin Square with 3 -week periods and balanced for residual effects. Cows received the same 
diet containing maize silage $(60 \%)$ and concentrate $(40 \%)$ which contained one of the three protein supplements: (1) low-protein treatment (LP), $5 \%$ soybean meal $+1.2 \%$ urea in the diet; (2) high-protein treatment with soybean meal (HP-SB), 19\% soybean meal in the diet; (3) high-protein supplement with formaldehyde-treated soybean meal (HP-FTSB), 12\% formaldehydetreated soybean meal $+1.2 \%$ urea in the diet. The total mixed diet (Tab. I) for ad libitum intake was fed to the cows twice daily after each milking.

Milk yield and DMI were recorded daily and cow body weight was recorded weekly.
Daily and weekly samples were collected for maize silage and concentrate, respectively, to estimate their DM composition. A representative sample of each feed was prepared during each period and analysed in order to determine its chemical composition and nutritive value. Milk samples from three consecutive daily milkings were collected every week and analysed for fat and protein contents. During the 3rd week of each experimental period, $10-\mathrm{ml}$ blood samples were drawn off from the tail vessels before the morning meal and were analysed for urea, glucose, NEFA, BHBA, plasma proteins and insulin.

Table I. Composition of diets and feeding values of the experimental complete diets.

\begin{tabular}{lccc}
\hline & LP $^{1}$ & HP-SB $^{2}$ & HP-FTSB $^{3}$ \\
\hline & & $(\%)$ Diet & \\
\cline { 2 - 4 } Maize silage & 60 & 60 & 60 \\
Concentrate & 32.3 & 19.5 & 25.3 \\
SBM & 5 & 19 & 0 \\
FT-SBM & 0 & 0 & 12 \\
Urea & 1.2 & 0 & 1.2 \\
Mineral and vitamin premix & 1.5 & 1.5 & 1.5
\end{tabular}

\begin{tabular}{lccc}
\hline & \multicolumn{3}{c}{$(\%) \mathrm{DM}$} \\
\cline { 2 - 4 } $\mathrm{DM}^{\mathrm{a}}$ & 51.0 & 50.6 & 51.5 \\
$\mathrm{OM}^{\mathrm{b}}$ & 92.6 & 93.7 & 92.6 \\
$\mathrm{CP}^{\mathrm{c}}$ & 14.1 & 16.5 & 17.0 \\
$\mathrm{NDF}^{\mathrm{d}}$ & 38.0 & 36.3 & 37.8 \\
$\mathrm{ADF}^{\mathrm{e}}$ & 18.5 & 18.0 & 18.4 \\
$\mathrm{ADL}^{\mathrm{f}}$ & 1.8 & 1.7 & 1.8 \\
$\mathrm{NE}_{\mathrm{L}}{ }^{\mathrm{g}}\left(\mathrm{UFL} \cdot \mathrm{kg}^{-1}\right.$ of DM) & 0.93 & 0.96 & 0.94 \\
$\mathrm{PDIA}^{\mathrm{h}}\left(\mathrm{g} \cdot \mathrm{kg}^{-1}\right.$ of DM) & 30 & 51 & 60 \\
$\mathrm{PDIN}^{\mathrm{h}}\left(\mathrm{g} \cdot \mathrm{kg}^{-1}\right.$ of DM) & 87 & 111 & 115 \\
$\mathrm{PDIE}^{\mathrm{h}}\left(\mathrm{g} \cdot \mathrm{kg}^{-1}\right.$ of DM) & 83 & 105 & 111
\end{tabular}

${ }^{1}$ Low protein; ${ }^{2}$ soybean meal; ${ }^{3}$ formaldehyde-treated soybean.

${ }^{\mathrm{a}}$ Dry matter; ${ }^{\mathrm{b}}$ organic matter; ${ }^{\mathrm{c}}$ crude protein; ${ }^{\mathrm{d}}$ neutral detergent fibre; ${ }^{\mathrm{e}}$ acid detergent fibre; ${ }^{\mathrm{f}}$ acid detergent lignin; ${ }^{\mathrm{g}}$ estimated using the equations of Vermorel [22] and expressed according to the French feed unit system, $1 \mathrm{UFL}=7.11 \mathrm{MJ}$ of $\mathrm{NE}_{\mathrm{f}} ;{ }^{\mathrm{h}}$ dietary protein truly digested in the small intestine (PDIA), protein truly digested in the small intestine allowed by N (PDIN) or energy (PDIE) and fermented in the rumen, and estimated using the equations of Vérite and Peyraud [24] according to the French feed unit system; ${ }^{i}$ contains: $20 \%$ barley, $21.5 \%$ wheat, $37 \%$ beet pulp, $17 \%$ wheat bran, $2 \%$ animal fat, $2 \%$ molasses, $0.5 \%$ calcium bicarbonate, $1 \%$ sodium bicarbonate and $1 \%$ sodium chloride. 


\subsection{Chemical analyses}

Chemical analyses were performed on dry feed samples that had been ground using a 0.8-mm mill. DM, OM, ADF and CP contents were analysed according to the AOAC methods [2], and the NDF content as described by Van Soest et al. [21] (procedure A). Protein and fat contents of milk were determined by infrared analysis (Milkoscan; Foss Electric, Hillerød, Denmark) [2]. Blood samples were prepared and analysed for urea, glucose and NEFA as described by Guinard et al. [10]. Insulin, BHBA and plasma proteins were determined as described by Faverdin et al. [9].

\subsection{Statistical analysis}

Data were analysed statistically using the GLM procedure of SAS [19]. The statistical model of variance analysis was the following:

$$
\begin{aligned}
\mathrm{Y}_{\mathrm{ijkl}}= & \mu+\mathrm{MY}_{\mathrm{i}}+\mathrm{C}_{\mathrm{j}}\left(\mathrm{MY}_{\mathrm{i}}\right)+\mathrm{P}_{\mathrm{k}}+\mathrm{T}_{1} \\
& +\operatorname{preT}_{\mathrm{m}}+\mathrm{T}_{1} \times \mathrm{MY}_{\mathrm{i}}+\mathrm{e}_{\mathrm{ijkl}}
\end{aligned}
$$

$\mathrm{Y}_{\mathrm{ijkl}}=$ experimental variable; $\mu=$ mean; $M Y_{i}=$ pre-treatment milk yield effect (high or medium); $\mathrm{C}_{\mathrm{j}}=$ cow effect; $\mathrm{P}_{\mathrm{k}}=$ period effect; $\mathrm{T}_{1}=$ treatment effect; pre $_{\mathrm{m}}=$ previous treatment effect; $\mathrm{T}_{1} \times \mathrm{MY}_{\mathrm{i}}=$ interaction between treatment effect and milk yield effect; $\mathrm{e}_{\mathrm{ijkl}}=$ residual. The milk yield effect was tested with the error $\mathrm{C}_{\mathrm{j}}\left(\mathrm{MY}_{\mathrm{i}}\right)$.

Four orthogonal contrasts were made in order to test the effect of some treatments on the experimental variables: (1) the effect of dietary protein content (PDIA = LP vs. $\mathrm{HP}$ ); (2) the effect of formaldehyde treatment (FT = HP-SB vs. HP-FTSB) compared to normal soybean meal; (3) the interaction between the pre-treatment milk yield and the dietary protein content (PDIA $\times$ MY); and (4) the interaction between the formaldehyde treatment and the pre-treatment milk yield $(\mathrm{FT} \times \mathrm{MY})$. Statistical difference was determined at $P<0.05$.

\section{RESULTS}

No significant interaction was found between the level of pre-treatment milk yield of dairy cows and the treatments, so the contrasts (3) and (4) are not presented in the tables $(P>0.05)$.

\subsection{Intake and milk yield}

HP treatments brought about a significant increase in DMI $\left(+1.2 \mathrm{~kg} \cdot \mathrm{d}^{-1}\right)(P<0.05)$, milk yield $\left(+1.8 \mathrm{~kg} \cdot \mathrm{d}^{-1}\right), 4 \%$ FCM yield $\left(+2.5 \mathrm{~kg} \cdot \mathrm{d}^{-1}\right)$, protein content $\left(+0.8 \mathrm{~g} \cdot \mathrm{kg}^{-1}\right)$, fat content $\left(+1.9 \mathrm{~g} \cdot \mathrm{kg}^{-1}\right)$, protein yield $\left(+82 \mathrm{~g} \cdot \mathrm{d}^{-1}\right)$ and fat yield $\left(+138 \mathrm{~g} \cdot \mathrm{d}^{-1}\right)($ Tab. II $)$ compared to LP treatment (Tab. II). However, the HP-FTSB treatment of soybean did not affect intake $(P>0.05)$ (Tab. II) but significantly decreased $(P<0.05)$ the protein content of milk compared to HP-SB treatment. On the other hand, the high-producing dairy cows ate more than mediumproducing cows receiving LP treatment $\left(+2.3 \mathrm{~kg} \cdot \mathrm{d}^{-1}\right)(P<0.05)$, but DMI increased similarly with protein supplements in both groups of cows. Protein and energy balances did not differ in both groups $(P>0.05)$.

\subsection{Blood plasma analysis}

HP treatments significantly increased $(P<0.05)$ the plasma concentrations of urea $\left(+13.6 \mathrm{mg} \cdot \mathrm{dL}^{-1}\right)$ and protein $\left(+0.3 \mathrm{~g} \cdot \mathrm{dL}^{-1}\right)$, but no significant effect was observed in plasma concentrations of insulin, glucose or BHBA (Tab. III). Compared to HP-SB treatment, plasma concentrations of NEFA were significantly higher in cows fed the HP-FTSB diet $(P<0.05)$ (Tab. III).

\section{DISCUSSION}

In this trial, the significant increases observed in DMI were dependent on improvements in the PDIE content of diets; such results are consistent with other 
Table II. Effects of soybean meal or formaldehyde-treated soybean protein supplementation on intake, milk yield and milk composition of dairy cows.

\begin{tabular}{lcccccc}
\hline & LP $^{1}$ & HP-SB $^{2}$ & HP-FTSB $^{3}$ & RSD $^{4}$ & PDIA $^{5}$ & FT $^{6}$ \\
\hline DMI $\left(\mathrm{kg} \cdot \mathrm{d}^{-1}\right)$ & $23.2^{\mathrm{a}}$ & $24.5^{\mathrm{b}}$ & $24.2^{\mathrm{b}}$ & 1.0 & 0.007 & 0.467 \\
Milk yield $\left(\mathrm{kg} \cdot \mathrm{d}^{-1}\right)$ & $37.2^{\mathrm{a}}$ & $38.7^{\mathrm{b}}$ & $39.4^{\mathrm{b}}$ & 1.1 & 0.001 & 0.178 \\
$4 \%$ FCM yield $\left(\mathrm{kg} \cdot \mathrm{d}^{-1}\right)$ & $35.0^{\mathrm{a}}$ & $37.5^{\mathrm{b}}$ & $37.5^{\mathrm{b}}$ & 1.3 & 0.001 & 0.990 \\
Total fat $\left(\mathrm{g} \cdot \mathrm{d}^{-1}\right)$ & $1331^{\mathrm{a}}$ & $1468^{\mathrm{b}}$ & $1471^{\mathrm{b}}$ & 67 & 0.001 & 0.912 \\
Total protein $\left(\mathrm{g} \cdot \mathrm{d}^{-1}\right)$ & $102^{\mathrm{a}}$ & $1124^{\mathrm{b}}$ & $1095^{\mathrm{b}}$ & 32 & 0.001 & 0.059 \\
Milk composition & & & & & & \\
$\quad$ Fat $\left(\mathrm{g} \cdot \mathrm{kg}^{-1}\right)$ & $36.1^{\mathrm{a}}$ & $38.2^{\mathrm{b}}$ & $37.7^{\mathrm{ab}}$ & 2.0 & 0.035 & 0.542 \\
$\quad$ True protein $\left(\mathrm{g} \cdot \mathrm{kg}^{-1}\right)$ & $27.8^{\mathrm{a}}$ & $29.2^{\mathrm{b}}$ & $28.0^{\mathrm{a}}$ & 0.5 & 0.001 & 0.001 \\
Nutrient balance & & & & & & \\
$\quad \mathrm{NE}\left(\mathrm{UFL} \cdot \mathrm{d}^{-1}\right)$ & -0.4 & 0.3 & -0.4 & 0.96 & 0.432 & 0.105 \\
$\quad$ PDI $\left(\mathrm{g} \cdot \mathrm{d}^{-1}\right)$ & $-71^{\mathrm{a}}$ & $413^{\mathrm{b}}$ & $580^{\mathrm{c}}$ & 107 & 0.001 & 0.004 \\
\hline
\end{tabular}

${ }^{1}$ Low protein; ${ }^{2}$ soybean meal; ${ }^{3}$ formaldehyde-treated soybean; ${ }^{4}$ residual standard deviation.

Contrasts: ${ }^{5}$ low dietary protein vs. high dietary protein; ${ }^{6}$ formaldehyde-treated supplement vs. non-treated supplement.

Table III. Effects of soybean meal or formaldehyde-treated soybean protein supplementation on some blood parameters.

\begin{tabular}{lcccccc}
\hline & LP & HP-SB & HP-FTSB & RSD $^{4}$ & PDIA $^{5}$ & FT $^{6}$ \\
\hline Urea $\left(\mathrm{g} \cdot \mathrm{L}^{-1}\right)$ & $0.25^{\mathrm{a}}$ & $0.40^{\mathrm{b}}$ & $0.38^{\mathrm{b}}$ & 0.52 & 0.001 & 0.357 \\
Glucose $\left(\mathrm{g} \cdot \mathrm{L}^{-1}\right)$ & 0.62 & 0.63 & 0.62 & 0.31 & 0.691 & 0.369 \\
NEFA $\left(\mathrm{mmol} \cdot \mathrm{L}^{-1}\right)$ & $0.11^{\mathrm{a}}$ & $0.12^{\mathrm{a}}$ & $0.20^{\mathrm{b}}$ & 0.07 & 0.103 & 0.022 \\
Protein $\left(\mathrm{g} \cdot \mathrm{L}^{-1}\right)$ & $84.7^{\mathrm{a}}$ & $88.0^{\mathrm{b}}$ & $87.9^{\mathrm{b}}$ & 2.7 & 0.009 & 0.973 \\
Insulin $\left(\mathrm{ng} \cdot \mathrm{L}^{-1}\right)$ & 0.47 & 0.52 & 0.53 & 0.18 & 0.534 & 0.891 \\
BHBA $\left(\mathrm{mmol} \cdot \mathrm{L}^{-1}\right)$ & 0.47 & 0.54 & 0.59 & 0.17 & 0.134 & 0.529 \\
\hline
\end{tabular}

${ }^{1}$ Low protein; ${ }^{2}$ soybean meal $;{ }^{3}$ formaldehyde-treated soybean; ${ }^{4}$ residual standard deviation.

Contrasts: ${ }^{5}$ low dietary protein vs. high dietary protein; ${ }^{6}$ formaldehyde-treated supplement vs. non-treated supplement.

findings $[3,18]$. The formaldehyde treatment of soybean meal did not affect DMI response. In some trials $[15,23]$, DMI increased, but not significantly $(P>0.05)$, when protein supplements were formaldehyde-treated $\left(+0.9 \mathrm{~kg} \cdot \mathrm{d}^{-1}\right.$ on average $)$. The overprotection of protein supplements with formaldehyde (> $0.3 \mathrm{~g} \cdot 100 \mathrm{~g}^{-1}$ of $\mathrm{CP}$ ) appears to decrease DMI, but not significantly, when such supplements are compared to non-treated supplements $[18,25]$.
This decrease may be due to the modifications in ruminal digestion caused by the low level of degradation of the formaldehydetreated soybean, which normally decreases rumen ammonia and reduces apparent nitrogen digestibility [4]. In this trial, the lower degradability of FTSB was compensated by urea addition in order to maintain a sufficient level of degradable nitrogen in the rumen. Some previous works have shown that the nature of degradable nitrogen in the 
rumen could slightly affect NDF digestibility [17] but does not significantly modify the digestibility of a maize silage-based diet. The increases in DMI in this trial are mainly due to a higher amino acid supply to the cows, independently of the type of supplement used.

The second objective of this work was to determine if the DMI response to protein supplement was related to the milk potential and nutrient requirements of the cows. In this trial, the lower milk yield of the medium group was associated with a lower DMI. Thus the energy and protein balances of the medium- and high-producing dairy cows were similar. The milk yield of the medium group was probably much more limited by nutrient availability than by mammary gland capacity. In this case, the similar DMI response of the two groups is logical. Nevertheless, the mechanisms involved in the DMI increase induced by protein supplements $(P<0.05)$ (Tab. II) are largely unknown.

The significant increase in milk yield observed with HP treatments is due to the PDIE content of diets, and should not depend on the kind of protein source of the supplement $(P<0.05)$ (Tab. II). The slightly higher improvement in milk yield observed in cows receiving HP-FTSB treatment compared to those fed a HP-SB supplement $\left(+0.7 \mathrm{~kg} \cdot \mathrm{d}^{-1}\right)$ could be explained by body reserve mobilization as reflected by energy balance $(P<0.05)$ (Tab. II) and plasma concentration of NEFA $(P<0.05)$ (Tab. III). Thus it should not be linked to the formaldehyde treatment or to a better use of amino acids by the mammary gland $[6,8]$. However, the protein content of milk $\left(+1.2 \mathrm{~g} \cdot \mathrm{kg}^{-1}\right)$ is significantly higher in cows fed an HP-SB supplement $(P<0.05)$ (Tab. II) than those fed an HP-FTSB treatment. Formaldehyde treatment of soybean meal could significantly reduce the amount of some amino acids absorbed from the small intestine and consequently affect their use by the mammary gland in cows that are fed such diets [5].

\section{CONCLUSION}

Intake, milk yield and other zootechnical parameters in dairy cows are seen to increase with the dietary protein content without any interaction with the milk yield. At the same level of PDIE and PDIN input into the diet, formaldehyde-treated or nontreated supplements have a similar and significant effect on DMI and milk yield compared to dairy cows fed a low-protein diet. However, the formaldehyde treatment significantly decreases the protein content of milk.

\section{ACKNOWLEDGMENTS}

The authors thank Roger Papin and his staff for care of the animals during the experiment. They are also grateful to the laboratory staff at the Unité Mixte de Recherches Production du Lait, 35590 Saint-Gilles - France.

\section{REFERENCES}

[1] Aharoni Y., Arieli A., Tagari H., Lactational response of dairy cows to change of degradability of dietary protein and organic matter, J. Dairy Sci. 76 (1993) 3514-3522.

[2] AOAC (Official Methods of Analysis), Association of Official Analytical Chemists, Washington, DC, 1997.

[3] Baker M.J., Amos H.E., Nelson A., Williams C.C., Froestschel M.A., Undegraded intake protein: Effects on milk production and amino acid utilization by cows fed wheat silage, Can. J. Anim. Sci. 76 (1996) 367-376.

[4] Chalupa W., Rumen bypass and protection of proteins and amino acids, J. Dairy Sci. 58 (1975) 1198-1218.

[5] Crawford J.R.J., Hoover W.H., Effects of particle size and formaldehyde treatment of soybean meal on milk production and composition for dairy cows, J. Dairy Sci. 67 (1984) 1945-1952.

[6] Crooker B.A., Clark J.H., Shanks R.D., Hatfield E.E., Effects of ruminal exposure on the amino acid profile of heated and formaldehyde-treated soybean meal, J. Dairy Sci. 69 (1986) 2648-2657.

[7] Cunningham K.D., Cecava M.J., Johnson T.R., Ludden P.A., Influence of source and amount of dietary protein on milk yield by cows in early lactation, J. Dairy Sci. 79 (1996) 620-630. 
[8] Erfle J.D., Sauer F.D., Mahadevan S., Teather R.M., Response of lactating dairy cows to formaldehyde-treated soybean meal when fed with control or urea-treated corn silage, Can. J. Anim. Sci. 66 (1986) 85-95.

[9] Faverdin P., Bareille N., Vérité R., Effects of rumen energy supply timing on feed intake control in lactating dairy cows, J. Dairy Sci. 82 (1999) 2443-2454.

[10] Guinard J., Rulquin H., Effect of graded amounts of duodenal infusions of casein on mammary uptake in lactating cows. I. Major nutrients, J. Dairy Sci. 77 (1994) 2221.

[11] Hensen J.E., Schingoethe D.J., Maiga H.A., Lactational evaluation of protein supplements of varying ruminal degradabitlities, J. Dairy Sci. 80 (1997) 385-392.

[12] Keery C.M., Aamos H.E., Effects of source and level of undegraded intake protein on nutrient use and performance of early lactation cows, J. Dairy Sci. 76 (1993) 499-513.

[13] Lundquist R.G., Otterby D.E., Linn J.G., Influence of formaldehyde-treated soybean meal on milk production, J. Dairy Sci. 69 (1986) 1337-1345.

[14] Mabjeesh S.J., Arieli A., Zamwell S., Tagari H., Heat-treated whole cottonseed versus maize gluten meal as a rumen undegradable protein supplement for lactating dairy cows, Livest. Prod. Sci. 55 (1998) 249-259.

[15] Muller L.D., Rodriguez D., Schingoethe D.J., Formaldehyde treated whey protein concentrate for lactating dairy cattle, J. Dairy Sci. 58 (1975) $1847-1855$.

[16] Mustafa A.F., Mckinnon J.J., Christensen D.A., Protection of canola (low glucosinolate rapseed) meal and seed protein from ruminal degradation, Asian-Aust. J. Anim. Sci. 13 (2000) 535-542.
[17] Peyraud J.L., Le Liboux S., Vérité R., Effet du niveau et de la nature de l'azote degradable sur la digestion ruminale d'un régime à base d'ensilage de maïs chez la vache laitière, Reprod. Nutr. Dev. 37 (1997) 313-328.

[18] Rae R.C., Ingalls J.R., Mckirdy J.A., Response of dairy cows to formaldehyde-treated canola meal during early lactation, Can. J. Anim. Sci. 63 (1983) 905-915.

[19] SAS, SAS User's Guide: Statistics, Version 6 Edition, SAS Inst Inc, Cary, NC, USA, 1987.

[20] Stock R., Klopfenstein T., Brink D., Lowry S., Rock D., Abrams S., Impact of weighing procedures and variation in protein degradation rate on measured performance of growing lambs and cattle, J. Anim. Sci. 57 (1983) 1276-1285.

[21] Van Soest P.J., Robertson J.B., Lewis B.A., Methods for dietary fiber, neutral detergent fiber, and nonstarch polysaccharides in relation to animal nutrition, J. Dairy Sci. 74 (1991) 3583-3597.

[22] Vermorel M., Nutrition énergétique, in Jarrige R. (Ed.), Alimentation des bovins, ovins et caprins, INRA, Paris, France, 1988, pp. 57-74.

[23] Vérité R., Journet M., Utilisation des tourteaux traités au formol par les vaches laitières. II. Effets sur la production laitière du traitement des tourteaux et du niveau d'apport azoté au début de la lactation, Ann. Zootech. 26 (1977) 183-205.

[24] Vérité R., Peyraud J.L., Nutrition azotée, in: Jarrige R. (Ed.), Alimentation des bovins, ovins et caprins, INRA, Paris, France, 1988, pp. 75-93.

[25] Wachira J.D., Satter L.D., Brooke G.P., Pope A.L., Evaluation of formaldehyde-treated protein for growing lambs and lactating cows, J. Anim Sci. 39 (1974) 796-807.

[26] Wattiaux M.A., Combs D.K., Shaver R.D., Lactational responses to ruminally undegradable protein by dairy cows fed diets based on alfalfa silage, J. Dairy Sci. 77 (1994) 1604-1617. 